\title{
A Learnership Programme for Student Teachers: A Partnership between a School and an Open Distance Learning Institution
}

\author{
Dr Alena van Schalkwyk
}

\author{
Department Curriculum and Instructional Studies, University of South Africa, Pretoria, South Africa
} email: vschaa1@unisa.ac.za

\author{
Doi:10.5901/mjss.2014.v5n20p1029
}

\begin{abstract}
This research explored the possible advantages of a partnership, grounded in a learnership programme, between a school and an Open Distance Learning Institution to address the need for more and better qualified teachers. $A$ headmaster at a primary school in Gauteng felt that this need for qualified teachers with the necessary teaching expertise could be addressed by implementing an apprenticeship or internship programme similar to that employed in the corporate world. A learnership programme was created under the supervision of the headmaster and with the approval of rest of the staff, whereby participating student teachers would enrol for a professional teaching degree at an Open Distance Learning Institution while completing the practical teaching component of the degree programme at the school. The findings of this research relied mainly on qualitative data obtained through interviews with the participating student teachers. These findings were supported by profiling the participating student teachers, thus, obtaining quantitative data. By exploring and comparing the student teachers' comments there emerged certain identifiable themes based on the theoretical framework of situated learning and workintegrated learning. The benefits for all the participants in this learnership programme were identified. Conclusions as well as recommendations were made in regard to the practical implications of a partnership-learnership programme between schools and an Open Distance Learning Institution in the future.
\end{abstract}

Keywords: mentor teachers; situated learning; student teachers; teaching practice; work-integrated learning (WIL)

\section{Introduction}

After the first democratic election in 1994, seventeen education departments were amalgamated into one national education department. Each of the nine new provinces still retained some measure of control of the education institutions within its respective region; however, this was subject to central government policies. The new national education system was introduced by the South African Schools Act 84 of 1996 (SASA), which amended or repealed all previous legislation and provided new norms and standards for education and training, including teacher training. Since then South Africa has also embarked on a policy of closing and incorporating teacher training colleges into universities and technikons in an attempt to promote educational equity but resulting in a reduction in the number of qualified teachers (Gouws 2012).

To counteract the shortage of skilled workers the Education, Training and Development Practices Sector Education and Training Authority (ETDP SETA) was established on 20 March 2000, as one of the 25 Sector Education and Training Authorities (SETAs) by the South African government. This was part of the Skills Development Strategy Act 97 of 1998. The aim was to make South Africa globally competitive by improving the skills levels of the South African people through the implementation of the National Skills Development Strategy (NSDS) and thereby supporting the qualifications of the nation's workforce with the addition of the required cognitive and practical skills (Mawoyo \& Robinson 2005:109).

One of the ETDP SETA core divisions is its learnerships and skills programmes. Both these programmes must be delivered by accredited providers such as an open and distance learning (ODL) institution. A learnership programme (LP) can be defined as a combination of structured learning and workplace experience which will culminate in a qualification (ETDP SETA 2002b). A learnership model for education and training was introduced in South Africa in 2001, as a route to obtain a qualification that integrates structured theoretical learning at a higher or further education training institution, with practical work-integrated learning (WIL) (Mawoyo \& Robinson 2005:109).

The current information avalanche and advances in technology have brought about changes in society that led to high standards of expertise expected from teachers (Creth 1986; Esteve 2000:197; Marais 2010:188; The Economist 2011). Therefore the practical training of student teachers should also change to prepare them better for this rapidly changing world and teaching environment. Certain countries, for example Austria and Germany, have a tradition of 'education always tied to demand' and, therefore, they combine apprenticeships with formal schooling for the young (The 
Economist 2013:30). A positive outcome of vocational education and training through WIL (namely internships, apprenticeships, or learnerships) is that the 'apprentices' often find it easier to find employment when they finish their studies as their training is embedded in the practical application and demands of their vocation (ETDP SETA 2002a:4; The Economist 2013:30). It is also important that training institutions and employers look at what contributions they can make to improve the quality of teaching as only 3000 out of 24000 schools in South Africa have been classified as functional schools (Gouws 2012:9). With this in mind, this research addresses the following question:

\begin{abstract}
If the professional work environment is continually changing, and requires teachers to both draw on deep theoretical knowledge and make sound judgment calls, regardless of the teaching situation, could the next generation of teachers be prepared better for this daunting task by creating WIL opportunities through a LP as a partnership between a school and an ODL institution? (Shulman 2004:5.)
\end{abstract}

To answer this question, the research explores the potential and opportunities provided for student teachers by the primary school adopting a LP within an ODL context. In the following section I shall provide background information on a LP and the theoretical framework supporting the validity of LPs for student teachers followed by a discussion of the methodology used in this research. In the last section, there will be a discussion of the potential and actual impact of the LP on the professional development of the student teachers who participated in this specific LP at the primary school while studying at an ODL institute.

\title{
2. The Steps Taken by the Headmaster to Create an Accredited Learnership Programme (LP)
}

In an effort to generate a pool of highly skilled qualified teachers to enable him to manage his school efficiently the headmaster of a former model C primary school on the East Rand introduced a LP at his school in 1999. Due to his experience in corporate training and his involvement in several professional areas of apprenticeship systems, he had the vision that a type of apprenticeship programme could be adapted as a LP in the education field (Shulman 2004:337). The LP proposed by the headmaster combines full-time work-based experience at the school with part-time structured learning via an ODL institution (ETDP SETA 2002a:4). He approached an ODL institution, namely the University of South Africa (Unisa), to discuss the possibility of the institution collaborating with the school as an academic partner in the LP. The criteria and roles for all the LP participants at this school were formulated by the headmaster and his senior supporting staff.

This LP, adapted to suit the needs of this specific school, was one of the first LPs in Gauteng that complied with the criteria set by the SETAs. For the LP to be legally recognised, the school (as the employer and skills developer) had to register as a training college and adhere to the following procedures:

- Register with the Department of Labour;

- register with the ETDP SETA (2002b) as a training centre, with the headmaster as the chief trainer;

- Register teachers, who are recognised as highly skilled in their field, as mentors after they have completed a recognised mentorship qualification at the University of Witwatersrand (WITS) (Clark 2007: 10).

- Register the student teachers provisionally with the South African Council of Educators (SACE) to enable these student teachers while studying to legally teach, supervised or unsupervised, in a South African school (see SACE Act 31 of 2000). This was done using the same motivation advanced when many unqualified teachers employed in township schools were registered by SACE based on their 'teaching experience' and the same legal implications should the student teachers get injured at the work place (Clark 2009).

- Sign a contract with each of the student teachers individually which would include several issues of concern, for example what stipend is to be paid during the training period. There also had to be a learnership agreement drawn up between the learner (student teacher), education provider (the ODL institute) and employer (the school) (ETDP SETA: 2002a:4).

- The school also assisted the participating student teachers with their official enrolment at Unisa, an ODL institution, for a qualification registered with the National Qualification Framework (NQF) (Clark 2009). Due to the ODL institution's character of transferring pedagogic knowledge at a distance, the LP student teachers could work at their own individual pace and time. There was the advantage of applying the theoretical knowledge gained from their studies immediately in 'hands-on' WIL experiences in the classrooms (McLaughlin 2004:48).

- The identification of student teachers who would be suitable candidates to participate in the LP was a key issue as this aspect could determine the success of this specific LP. Although the student teachers mostly 
completed their BEd in 4 to 6 years, they could remain in this LP for up to 10 years (the maximum time allowed by the ODL institute for a BEd degree), depending on their yearly progress and personal circumstances (Clark 2007). They also had to fit in with the ethos of this school. Therefore, the following operational requirements were used as criteria:

- identifying skills which the school required

- who could fulfil the equity requirements

- who would agree to enrol at an ODL institution of the school's choice for an accredited teaching qualification of their choice while teaching at the school (Clark 2009).

This LP differs from the conventional models of teaching practice associated with teacher education in South Africa where student teachers only go to a school for a short time during a specified period, as required by the degree they are enrolled for. The ideal-typical model of a learnership envisaged by ETDP SETA (2002b) would allow a student teacher to spend between one- and two-thirds of their weekly programme time in a school to receive practical guidance with regard to the application of teaching methodologies in the classroom. This LP complied with this ideal because it is linked to an ODL institution, allowing the participating student teachers to spend most of their time in a school, except for those days when they are preparing for and writing their examinations.

Most educators believe that WIL should be integrated into the preparation of future teachers (Slick 1995). As knowledge is a process and not a product, the student teacher should rather participate in the process that makes the establishment of a knowledge base possible and at the same time implement it in practical teaching activities. In this way, the student teacher's WIL experiences become part of the situated learning process (Shulman 2004:60-61).

\section{A Theoretical Framework for the Validity of the Establishment of Learnership Programmes (LPs)}

The historical significance of apprenticeships as a system to produce knowledgeable, skilled persons has too often been overlooked as a possibility for the teaching profession, since apprenticeships were originally associated with hand craft production (Lave \& Wenger 1991:62-63). The idea of apprenticeships was revived by Lave and Wenger in 1991, when they began supporting the notion of the learners (student teachers) learning through apprenticeships (or the twentieth century term, learnerships) while participating in school communities as CoP. The student teachers 'learn by doing', as legitimate peripheral participants, situated at a school (as a CoP). The legitimate peripheral participation refers to the relations between the student teachers (as the learners) as they participate in WIL, gradually mastering the teaching task in their CoP under the auspices of their mentor teachers (as the masters) (Lave \& Wenger 1991:31). According to Maeroff (1988:56) the reason why schools exist is to assist children to learn and, therefore, school communities should also have the responsibility to assist student teachers, through a LP, to learn about the practical aspects of the profession through teaching and learning activities found at a school.

The research on this specific LP is grounded in the theory of situated learning and WIL, supported by the three elements of Wenger's situated learning in a CoP, which are identified below (Grabinger \& Dunlop 1996:7-8; Wenger 2000:229).

- The first element is the notion that knowledge is not a product to be accumulated, but an active and evolving WIL process in which the student teacher as the learner attempts to make sense out of the teaching-learning world of the classroom as a CoP (CHE 2011; Grabinger \& Dunlop 1996:7). According to WIL and the situated learning theory there is a continuous reciprocal interaction as a joint enterprise (the LP) between all the members of the community to ensure that the learning activities are productive and successful, as well as assisting student teachers to understand themselves in relationship to others (Hanko 1999:76; Wenger 2000:229). These role players, namely the mentor teachers and the student teachers, are bound together by their collective understanding and accountability of what the LP and the school community expect of them. The student teachers must be enabled to contribute through legitimate peripheral participation in teaching activities to this joint enterprise.

- The second element is the notion that student teachers internalise their knowledge in personal ways that it enable them to use that knowledge later in contextualised problem-solving learning situations. WIL therefore takes place in real classroom situations enabling the student teachers to make it meaningful and their own as they establish norms and relationships of mutuality that reflect these interactions (CHE 2011:55). Student teachers experience feelings of belonging and sharing of knowledge and skills as they interact during mutually productive social engagements with one another and their mentor teachers. The student teachers contribute productively as members to their school's CoP through this mutual social engagement in a 
constructed situated learning context (Wenger 2000:229);

- The third element is ascribed to the importance of collaboration as a meaningful WIL activity, on individual as well as cultural level, and such collaboration is negotiated within a social context. A common understanding and shared meanings are developed through WIL interaction among peer student teachers and mentor teachers as they test the viability of their understandings, theories and conjectures through collaborative interactions (CHE 2011:55-57; Woolfolk 2007:481). It also helps to build the student teacher's self-esteem and professional confidence. This, according to Wenger (2000:229), is collaboration in a shared repertoire of communal resources. To become competent is to have access to this shared repertoire enabling the student teachers to apply practical teaching learning activities appropriately in classrooms, while they are working towards completing their professional qualifications.

As new demands are continuously been placed on education, due to increasingly complex societal needs, educators agree that student teachers must learn to solve problems and think independently to develop life-long learning skills (Grabinger \& Dunlop 1996:1). Jarvis (2009: 11) states that students teachers do not learn from what we tell them, they learn from their practical teaching experiences. 'Work' experiences or WIL through social interactions have long been widely accepted as an important part of teacher education. A LP that places student teachers in a situated social learning environment where they can practice solving teaching and learning problems in a collaborative and constructive manner could address these issues (CHE2011; Grabinger \& Dunlop 1996:3).

\section{Research Design}

The school where this LP has been implemented is a government school in an urban area that serves a predominantly middle class community. It is a co-educational school with a racially mixed school population, but the professionally qualified teachers are mainly white and female. There were 19 student teachers who enrolled in the LP of this school and agreed to be interviewed during 2012. The quantitative profiling of the student teachers participating in this research and the LP at this school indicated the following:

- There were 17 females of which nine were between the ages of 20-25 years, five were between the ages of 26 to 30 years and the remaining three were over 30 years of age.

- The two male participants were between the ages of 20 to 25 years.

- For the 19 student teachers participants' years in the LP, see chart 1.

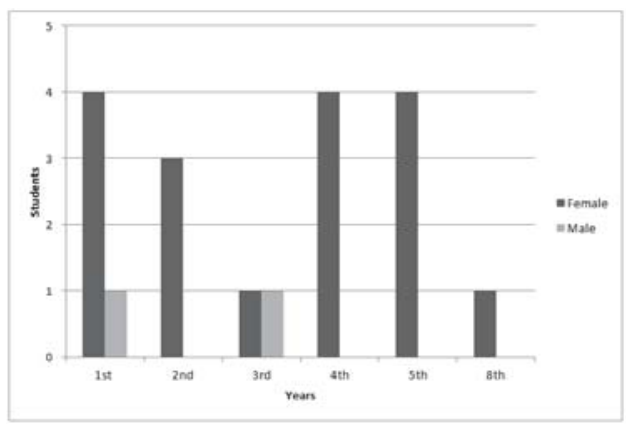

Chart 1: LP - The participating student teachers' enrolment years

- Since the implementation of this LP, 45 student teachers have been part of this LP. See chart 2 for their performance profile. 


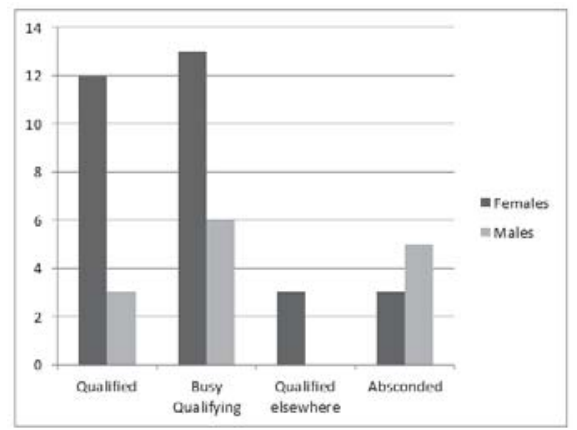

Chart 2: LP - The student teachers' performance profile

In this research, the process is often more important than the outcome as the process forms part of the outcome (Henning 2004:41). A limitation was that only the comments of student teachers were important. Further research will have to explore the viewpoints of the mentor teachers. Informed feedback from the participants was obtained by qualitative means. Individual and group interviews were employed to collect data regarding the experiences of the student teachers during their participation in this LP (Mack, Woodsong, MacQueen, Guest \& Namoy 2005:1). To eliminate and minimise the element of bias, certain strategies were applied such as allowing participants to express their feelings freely without being identified. The participants also had the option to withdraw at any stage of the research project. All ethical issues were adhered to as all the participating student teachers were fully informed at a general meeting that participation was completely voluntary and that their honest input regarding the LP would be invaluable to determine the benefits or not of this LP. Emerging themes was identified by exploring and comparing student teachers' comments in the interviews, before conclusions were be made for further research.

\section{Discussion of Findings}

Referring back to the theoretical framework of situated learning and WIL, the findings of this research can be grouped together and discussed under the following three themes, identified as follow:

\subsection{Learning activities as a joint enterprise}

The LP is developed around the needs of the student teachers and the school community as a joint enterprise of doing WIL teaching activities, collaboratively with the ODL institution, in the school. In a student-centred learning environment major emphasis is placed on developing intentional WIL as life-long learning skills through active involvement. Grabinger and Dunlop (1996:5-14) suggested that by cultivating an atmosphere of knowledge building learning school communities, collaborative learning via LPs among student teachers and mentor teachers, could become a joint enterprise. As skills and knowledge are best acquired within WIL contexts, this will help to promote vocational learning through specific teaching activities of student teachers under the auspices of mentor teachers in real classroom learning environments (Grabinger \& Dunlop 1996:6-7; Van Rensburg \& Rheeder 2012:53). By convincing most of his staff to participate in and support the LP, the headmaster created a shared purpose and joint enterprise in the school as a CoP, as prescribed by the situated learning theory. Student teacher G (female; age 20-25; $1^{\text {st }}$ year in LP) voiced the general opinion of all the participating student teachers when she stated, 'Teachers are keen to assist ... and there is definitely a team based support for us students, where help, support and information is (sic) readily available'. To be part of collaborating teaching is in itself a professional developmental experience, according to Pelletier (1995:XXIII).

The school also expected their student teachers to be accountable to this joint enterprise, as student teacher $B$ (female; age 20-25; $4^{\text {th }}$ year in LP) reiterated, 'It taught me more about the practical side of teaching...as you don't really understand what teaching entails until you start working full time.' Student teacher D (female; age 20-25; $5^{\text {th }}$ year in LP) felt that 'often people don't realise what teaching really entails... it's given me a head start' and, according to another student teacher E (male; age 20-25; $1^{\text {st }}$ year in LP) 'help me grow and move forward ... learn to become a suitable teacher'. According to Lave and Wenger (1991:33), the emphasis is on comprehensive understanding that involves the whole person rather than 'receiving' factual knowledge, that is meaningless unless made specific to the teaching-learning 
situation in the school. Student teachers should be encouraged to teach while they are studying to improve what and how they teach. They also had to learn how 'to balance teaching, marking, studying and exams" (student teacher L; female; age 26-30; $4^{\text {th }}$ year in LP) or as student teacher I (male; age 20-25; $3^{\text {rd }}$ year in LP) put it "manage your time". This was an important WIL experience for the student teachers as they became part of the school's socio-cultural CoP while these self-representations allowed them and the community to see them and itself in new ways. This was mentioned by student teacher B (female; age 20-25; $4^{\text {th }}$ year in LP) who said that it helped 'to fulfil my dream to be a teacher... I gained experience ....was able to better myself and be a better teacher'. The chance to participate actively in the school community thus made student teachers more aware of what teaching within their $\mathrm{CoP}$ entails.

This school's CoP also strives to maintain a spirit of inquiry among its all members. This was supported by the statements of the student teachers who all felt they benefitted by being actively engaged in the situated learning process with the school community. Student teacher A (female; age26-30; $5^{\text {th }}$ year in LP) confirmed that 'the "hands on" experience has been invaluable'. Furthermore, student teacher E (male; age 20-25; $1^{\text {st }}$ year in LP) stated that it 'puts us in a classroom from the beginning ... what to do and what not to do'. An opportunity to observe contrasting teaching styles alerted the student teachers to how they would want and not want to teach. Student teacher D (female; age 20-25; $5^{\text {th }}$ year in LP) supported this as she commented, '(the) learnership programme helped me to realise that teaching is the right job for me. I have also seen the type of teacher I don't want to become '. It is clear that in the school's CoP, the mentor teachers together in a joint enterprise with the student teachers, were continuously interactively collaborating, facilitating, sharing and spreading knowledge to improve their teaching practices.

\subsection{Learning activities through mutually productive social interaction}

In line with the situated learning theory, the principal took the initiative and showed leadership by establishing a LP at his school, relying on the mentor teachers and the ODL institution to support the LP. He also placed mentor teachers in charge of certain aspects of the LP as each of them had a guiding role to fulfil to ensure that the LP succeeds. Members of the community must get to know one another well enough to know how to interact productively and socially, and who to call on for help or advice (Wenger 2000:230). Each role player in the LP is aware of his/her role, the codes of behaviour and the shared principles that hold their school community together. Student teacher B (female; age 20-25; $3^{\text {rd }}$ year in LP) voiced the general feeling of the student teachers when she stated, 'You need a mentor teacher that will provide the best possible example for you to follow. Each has taught me something different'. Student teacher M (female; age 20-25; $1^{\text {st }}$ year in LP) also supported this statement when she iterated that well-qualified mentors 'rub off on you'. Furthermore, student teacher F (female; age 26-30; $5^{\text {th }}$ year in LP) felt she learned a lot and 'much more - much, much more through experience than studying.' This supported the situated learning theory as student teachers had to through mutual productive social interaction contextualise their own WIL in practical teaching situations to become full participants in the CoP (Lave \& Wenger 1991:29, 35).

Furthermore, the student teachers rated the passion for teaching displayed by mentor teachers, higher than their qualifications. When they discussed the examples set by their mentor teachers, student teacher N (female; age 26-30; $5^{\text {th }}$ year in LP) commented, 'Some teachers who are not 'highly' qualified are excellent teachers and help create a love of teaching.' These mentor teachers 'who has (sic) a lot of experience and a wealth of knowledge' (student teacher 0 ; female; age over 30; $4^{\text {th }}$ year in LP) inspired the student teachers to do their best to become excellent teachers and obtain their degree as soon as possible. This was also important to student teacher J (female; age 20-25; $4^{\text {th }}$ year in LP) as 'expert teachers have a "way about them" that no textbook has prescribed'. As in this case all the role players of the LP, namely the headmaster, the mentor teachers and the student teachers, are all participating and actively involved with their own and one another's teaching and learning activities as a mutual productive social interaction as knowledge is not a product to be accumulated, but an active and growing process to make sense of the community's purpose (Collins, Brown \& Holum 1991:38-39).

The student teachers also felt that the mentor teachers and student teachers must trust one another as they participate, collaborate and interact in the LP of their school's CoP (Du Plessis, Marais \& Van Schalkwyk 2011:30). As student teacher P (female; age 20-25; $2^{\text {nd }}$ year in LP) said, 'We all get opportunities to interact in the school's infrastructure.' This trust was evident in that mentor teachers gave the student teachers a lot of responsibility and encouragement (student teacher Q (female; age over 30; $4^{\text {th }}$ year in LP). The student teachers also mentioned that they always supported and helped one another.

The mentor teacher and student teacher must feel comfortable about working together to address problems together and being honest with each other. Student teacher R (female; age 20-25; $3^{\text {rd }}$ year in LP) mentioned that because some of the qualified mentor teachers also started their teaching careers as participants in the LP themselves, they could 
guide them in the 'right direction'. Mentor teachers provided the environment for student teachers to practice their newly acquired skills and bridge the complex gap between theory and practice (Pelletier 1995: XXI). The fact that the mentor teachers and the student teachers shared learning activities during mutually collaborative social interaction gave the student teachers 'a wonderful pool of knowledge and support', according to student teacher C (female; age 25-30; $4^{\text {th }}$ year in LP). She furthermore states, 'It allowed me to watch teaching learners first hand in order to see how to conduct myself and to be competent is to be able to engage with the community and be trusted as a partner in these interactions'. All the student teachers felt at ease with their mentor teachers and appreciated the mentor teachers' feedback and help regarding their teaching activities as all participants felt free to raise positive and troubling issues during these discussions (Wenger 2000:231).

Through the important partnership between mentor teachers and student teachers, receiving and giving one another help, all participants could expect that their contribution would be reciprocated in some way (Wenger 2000:230). That it also benefitted the mentor teachers is illustrated by the observation of student teacher A (female; age 26-30; $5^{\text {th }}$ year in LP) who said, 'I feel it forced some of the teachers to 'up their game' because they were being shown up by younger, excited learnership student teachers'. This LP thereby also gave the mentor teachers the insight to adapt their own teaching to the needs of their society or community (Esteve 2000:199-202). This demonstrates the important role of a collaborative partnership between the mentor teachers and the student teachers during social interactions to ensure that the LP functions well. This will also be highlighted in the recommendations of this research.

\subsection{Learning activities as collaborating in a shared repertoire}

The LP made it possible for the student teachers to be self-reflective regarding their teaching and ODL study activities while they were, at the same time, part of a school's social $\mathrm{CoP}$ with its own tradition and routines. Being reflective on its repertoire enables a community to understand its own state of development from multiple perspectives, reconsider assumptions and patterns, uncover hidden possibilities, and use this self-awareness to move forward (Wenger 2000:230). Student teacher A (female; age 26-30; $5^{\text {th }}$ year in LP) reflected, 'as the school has numerous learnerships I can see even more benefits like study groups, sharing the cost of textbooks. I was able to observe and learn from experiences and passionate teachers while building my own teaching skills and personality.'

It is also important in situated learning for the school community to transmit their knowledge and traditions to the new generation. In this LP this is done by enabling the student teachers to become competent by having access to this shared repertoire and the opportunity to use it appropriately (Wenger 2000:229). Student teacher G (female; age 20-25; $1^{\text {st }}$ year in LP) felt 'nothing can surmount to actual physical experience and putting the learnt theory in a real life context'. These shared 'hands-on' collaborative WIL and teaching experiences, as members of the school's socio-cultural community, were seen in a very positive light by the student teachers when viewing their own professional and personal growth during the LP. The student teachers had the following remarks in this regard, namely: 'learnership forces students to be proactive - be self-disciplined and serious about the programme. I matured much quicker than my friends which affected our relationships' (student teacher C: female; age 26-30; $4^{\text {th }}$ year in LP) and 'it placed me a few years ahead of my peers (student teacher J: female; age 20-25; $4^{\text {th }}$ year in LP). Student teacher $\mathrm{H}$ (female; age 20-25; $2^{\text {nd }}$ year in LP) also supported this as she mentioned that she has gained 'more confidence in myself'.

The fact that this school kept learning at the centre of its LP is illustrated by the following remarks of the participating student teachers. Student teacher K (female; age over 30; $8^{\text {th }}$ year in LP) felt she 'received far more assistance from my school and mentors than the ODL institution'. This point was supported by numerous student teachers and strongly stated by student teacher L (female; age 26-30; $4^{\text {th }}$ year in LP) that she 'would not have accomplished and learned half of what she did without the school'. The student teachers could, by doing and sharing teaching activities, identify gaps in their teaching knowledge and work with their mentor teachers to address these gaps. This learning experience could be even more valuable if the teaching learning experience is defined by the study material set by the participating ODL institution.

All the partners in a CoP should work together for one another's benefit as without the shared interactive collaboration, the community could become stagnant. This was supported by the comments of the LP student teachers in this research.

\section{Benefits Derived from the Learnership Programme (LP)}

It is clear that this LP has great benefits for all the participants, but only if and when they were all prepared to do what was expected from them. The student teachers identified several benefits for the school community, the student teacher, 
mentor teacher and ODL institution. These will be elaborated on below.

\subsection{The school community}

The school could select their own student teachers as well as regulate the size of their staff. Hereby the school received the benefit from reducing the learner-teacher ratio by employing the student teachers as full-time assistant teachers. The workload of mentor teachers was also reduced due to the assistance provided by the student teachers in the classroom. Therefore the school had smaller classes, affording each learner more personal and individual attention. This joint enterprise between the school, the mentor teachers and student teachers, helped to support a functional CoP as the student teachers were familiar with and trained according to the ethos of the school.

\subsection{The student teachers}

As they could earn an income, some student teachers, who otherwise would not have had the opportunity or the means to study, were able to enter the teaching profession and thus fulfilling their ambitions. It also provided students, who are unemployed, the opportunity to access the labour market as teachers (Newton 2012; Rademeyer 2012). Student teacher $\mathrm{H}$ (female; age 20-25; $2^{\text {nd }}$ year in LP) summed it up best: 'Without the LP it would have been (financially) difficult for me to study'. One of the outcomes of the LP is qualified teachers, who can be employed by the school and who have the capacity to immediately contribute meaningfully to the school community. It was agreed that the greatest benefit to the student teachers was the excellent balance between academic training from the ODL institution and the equal amount of practical training they got from the school. They qualify as seasoned teachers, having had exposure to many different hands-on practical teaching situations in the classroom as legitimate peripheral participants (Clark 2007:45; Wenger 2000).

\subsection{The mentor teacher}

The need to keep abreast of changes in the teaching profession and the subject field in which the teacher specialises arises shortly after a teacher starts teaching. The longer someone has been teaching, the greater the need for intervention that will keep the teacher up-to-date (Maeroff 1988:37). True partnership through mutually productive social interaction, creates a situation where the latest teaching trends and creative ideas are provided via the student teachers directly in the mentor teachers' classes (Pelletier 1995: XXI; Hanko 1999:76). As the school developed into a learning $\mathrm{CoP}$, with an ethos of learning, many of the mentor teachers have now started to further their studies to improve their own qualifications. Therefore, indirectly the on-site training at the school of the student teachers has contributed to some mentor teachers' own professional development. The mentor teachers' views regarding this LP could also of interest for further research.

\subsection{The ODL institute}

Van Rensburg and Rheeder (2012:53) suggest that the ODL institution should take a more holistic approach to WIL. The ODL institution's study material should reflect this collaborative WIL approach with the school communities striving for a closer partnership to accommodate the student teachers busy with LPs. In this regard student teachers Q (female; age over 30; $4^{\text {th }}$ year in LP) would be happy if the ODL institution 'could offer a more learner friendly system'. The ODL institution is also able to make use of all the latest technology e.g. involving e-learning and m-learning (Naidu 2010). By carefully designing technology pedagogically suitable material for blended learning to bridge the gap in space and time with the LP student teachers, it would be able to support these student teachers WIL experiences (Jarvis 2009:7-9; Juwah 2010:11). It is clear that the LPs could provide a good balance between the ODL's "secondary" theoretical experiences and the practical WIL student teachers could get from the schools. This type of partnership could lead to well-qualified student teachers who have practical WIL and teaching experience when they enter the teaching profession upon completion of their academic studies. These partnerships could also benefit the ODL institution as more student teachers could prefer to go the route of LP's to qualify for their teaching degree at ODL institutions that participate in and promote LP, instead of residential institutions.

The above-mentioned benefits by far outweighed the few disadvantages experienced, for example, student teachers who absconded and did not complete the LP due to difficulties experienced because of the demands of working and studying at the same time. The contribution the student teachers made to teaching activities at the school far 
outweighed the time lost while they were writing examinations. This research clearly supported the original aim of establishing this LP, namely to allow the student teachers to develop their potential vocational competencies as well as their teaching skills while studying. This enabled them to enter the teaching profession as more competent teachers when they completed their LP as they kept abreast with the latest developments in the teaching profession, while already contributing professionally.

\section{Conclusion and the Way Forward}

All the student teacher participants of this LP felt strongly that they function well in a school community with reciprocal collaboration and social interaction support between all the participants. Combining theoretical knowledge with practical experience bridges the gap between studying and working. The student teachers gained the theoretical knowledge from the ODL institution where they were enrolled for a qualification. At the same time the student teachers gained practical WIL experience by applying the theoretical knowledge in the classroom situation at the school where they are employed as part of the LP. The influence of this LP on this primary school's CoP has paid dividends in addressing their needs for a better learner-teacher ratio as well as well-qualified teachers. It is acknowledged that partnership relationships between schools and an ODL institution in training student teachers could only improve the current teacher training programmes. As this research indicated LPs such as this LP could be the future way forward for teacher training.

An ideal joint enterprise situation for a collaborative partnership already exists between a school community and an ODL institution because an ODL institution allows for the 'openness' of responsible access and alternative pathways for student teachers to gain their teaching qualifications. The LPs partnerships with ODL institutions also allow for greater accessibility to the teaching profession which could eventually lead to more students entering the teaching profession, as already indicated in this research. The shortage of well-qualified teachers could be solved by going the LP route with student teachers' training. While schools and ODL institutions are currently run as business enterprises the example of this LP, could serve as an inspiration and model for starting LPs or improving already established LPS.

\section{Acknowledgements}

The headmaster, John Clark, who implemented his vision of a LP, assisted by Karen Bellamy, the administrator and his 'right hand man'.

\section{References}

Clark, E. (2007). The influence of the learnership programme on the community of Norkem Park primary school. Unpublished research project for a Bachelor of Social Work (BSW)(SCK410B) at UNISA: Pretoria.

Clark, J.S. (2009). A presentation: growing your own staff. At Norkem Park Primary School in Kempton Park.

Collins, A., Brown, J.S., \& Holum, A. (1991). Cognitive apprenticeship: making thinking visible. American Educator, 15(3), 38-39.

Council on Higher Education (CHE). (2011). Work-Integrated learning: good practice guide. HE Monitor no.12 (August 2011). Pretoria: Council on Higher Education. ISBN978-1-919856-81-0.

Creth, S.D. (1986). Effective on-the-job training. USA: American Library Association.

Du Plessis, E.C., Marais, P., \& Van Schalkwyk, A. (2011). The role of lecturers as mentors in the assessment of student teachers. Progressio, 33(1), 23-42.

ETDP SETA (Education Training and Development Practices Sector Education Training Authority). (2002a). Learnerships \& skills programmes: policy and strategy of the ETDP SETA for learnerships and skills programmes. Rivonia. Also available: www.etdpseta.org.za.

ETDP SETA. (2002b). Annual report. RP number 134/2002. ISNB No.0-621-33124-4.

Esteve, J.M. (2000). The transformation of the teachers' role at the end of the twentieth century: new challenges for the future. Educational Review, 52(2), 197-207.

Gouws, J. (2012). Hou op kerm en kla - dóén. Rapport Nuus, (December 30), 9.

Grabinger, R.S., \& Dunlop, J.C. (1996). Rich environments for active learning: a definition. Association for Learning Technology Journal, $3(2), 5-34$.

Hanko, G. (1999). Increasing competence through collaborative problem-solving. Great Britain: David Fulton Publishers.

Henning, E. (2004). Finding your way in qualitative research. Pretoria: Van Schaik Publishers.

Jarvis, P. (2009). Teaching whole people through distance education. Institute for Open \& Distance Learning. ODL Occasional Lecture Series. ISBN =978-1-86888-617-3. Pretoria: Unisa.

Juwah, C, (2010). The impact of technology on distance education: implications for developing countries. Institute for Open \& Distance Learning. $5^{\text {th }}$ Lecture in the ODL Occasional Lecture Series (2010). ISBN =978-1-86888-675-3. Pretoria: Unisa Institute. 
Lave, J., \& Wenger, E. (1991). Situated learning: legitimate peripheral participation. Cambridge: Cambridge University Press.

Mack, N., Woodsong, C., MacQueen, K.M., Guest, G., \& Namoy, E. (2005). Qualitative research methods: a data collector's field guide. USA: Family Health International.

Maeroff, G.I. (1988). The empowerment of teachers: overcoming the crisis of confidence. New York: Teachers College, Columbia University.

Marais, P. (2010). Student teachers' experiences in teaching practice through ODL. Progressio, 32(2), 181-198.

Mawoyo, M., \& Robinson, M. (2005). The organization of pedagogy in a learnership model of teacher education. South African Journal of Education, 25(2), 109-114.

McLaughlin, T.H. (2004). Teaching as a practice and a community of practice: the limits of commonality and the demands of diversity, in J. Dunne, \& P. Hogan (Eds.), Education and practice: upholding the integrity of teaching and learning (pp.48-60). Cornwall: Blackwell Publishing.

Naidu, S. (2010). Unpacking the affordances of technology for e-learning. Institute for Open \& Distance Learning. 3rd Lecture in the ODL Occasional Lecture Series (2010). Pretoria: Unisa Institute.

Newton, J. (2012). Growing staff potential is the key to success. Star Work Place News (May) 9, 5.

Pelletier, C.M. (1995). A handbook of techniques and strategies for coaching student teachers: a guide for cooperating teachers, mentors, college supervisors, and teacher educators. Allyn \& Bacon: USA.

Rademeyer, A. (2012). Instituut pak min student. Beeld Nuus, (31 March), 10.

Shulman, L.S. (2004). The wisdom of practice. Essays on teaching, learning, and learning to teach. USA: Jossey-Bass printing.

Slick, G.A. (1995). Making the difference for teachers. The field experience in actual practice. California: Corwin Press Inc.

South Africa Council of Education (SACE) Act 31 of 2000. http://www.sace.org.za/registration/jit_default_14.Registration.html (Accessed August 21, 2012).

South African Schools Act (SASA) 84 of 1996. http://www.info.gov.za/acts/1996/a84-96pdf (Accessed August 22, 2012).

South Africa Skills Development Act 97 of 1998. http://www.acts.co.za/skills-development-act-1998/index.html?5 (Accessed August 22, 2012).

The Economist. (2011). Briefing reforming education: the great schools revolution. The Economist (September 17), $19-22$. Economist.com/print.

The Economist. (2013). German education and training: ein neuer deal? The Economist (June 1):30. Economist.com/print.

Van Rensburg, E., \& Rheeder, M. (2012). Work-integrated learning in an ODL context: the challenge of meeting student and mentor needs. Progressio, 34(3), 37-58.

Wenger, E. (2000).Communities of Practice and Social Learning Systems. SAGE Social Science Collection 7(2), 225-246.

Woolfolk, A. (2007). Educational psychology. Tenth edition. New York: Pearson. 